\title{
Towards a cysticercosis-free tropical resort island: A historical overview of taeniasis/cysticercosis in Bali
}

\author{
Putu Sutisna ${ }^{a, b, *}$, I. Nengah Kapti ${ }^{a, b}$, Toni Wandra ${ }^{c}$, Nyoman S. Dharmawan ${ }^{d}$, Kadek Swastika ${ }^{b}$,
} A.A. Raka Sudewi ${ }^{e}$, Ni Made Susilawathi ${ }^{f}$, I. Made Sudarmaja ${ }^{b}$, Tetsuya Yanagida ${ }^{g}$, Munehiro Okamoto ${ }^{h}$, Takahiko Yoshida', Meritxell Donadeu', Marshall W.

Lightowlers ${ }^{\mathrm{j}}$, Akira Ito ${ }^{\mathrm{k}, * *}$

${ }^{a}$ DEPARTMENT of Microbiology AND PARASITOLOGY, FACULTY of Medicine AND HEALTH Sciences, WARMADEWA University, DENPASAR, INDONESIA

${ }^{\mathrm{b}}$ DEPARTMENT of PARASITOLOGY, FACULTY of Medicine, UDAYANA University, DENPASAR, INDONESIA

${ }^{\mathrm{c}}$ DIRECTORATE of POSTGRADUATE, SARI MUTIARA INDONESIA University, MEDAN, INDONESIA

d DEPARTMENT of PARASITOLOGY, FACULTY of VETERINARY Medicine, UDAYANA University, DENPASAR, INDONESIA

${ }^{\mathrm{e}}$ UDAYANA University, DENPASAR, INDONESIA

${ }^{f}$ DEPARTMENT of Neurology, SANGLAH GENERAL HOSPITAL, FACULTY of Medicine, UDAYANA University, DENPASAR, INDONESIA

${ }^{g}$ LABORATORY of VETERINARY PARASITOLOGY, Joint FACULTY of VETERINARY Medicine, YAMAGUCHI University, YAMAGUCHI, JAPAN

${ }^{\mathrm{h}}$ PRIMATE RESEARCH Institute, Kyoto University, INUYAMA, JAPAN

' DEPARTMENT of SOCIAL Medicine, ASAHIKAWA MEDICAL University, ASAHIKAWA, HOKKAIDO, JAPAN

${ }^{\mathbf{j}}$ VETERINARY CLINICAL Centre, FACULTY of VETERINARY AND AGRICULTURAL Sciences, University of Melbourne, Werribee, VICTORIA, AUSTRALIA

${ }^{\mathrm{k}}$ DEPARTMENT of PARASITOLOGY, ASAHIKAWA MEDICAL University, ASAHIKAWA, JAPAN

\section{ARTICLEINFO}

\section{Key words:}

TAENIA solium

TAENIA SAGINATA

TAENIA ASIATICA

Bali

Indonesia

\begin{abstract}
A B S TRACT
Taeniasis and cysticercosis are known to be endemic in several Indonesian islands, although relatively little recent epidemiological data are available. As most Indonesian people are Muslims, taeniasis/cysticercosis caused by the pork tapeworm, TAENIA solium, has a restricted presence in non-Muslim societies and is endemic only among some Hindu communities on the island of Bali. Bali has long been known to be endemic for taeniasis/ cysticercosis; almost a century ago levels of cysticercosis of 20-30\% were described in cattle and $2-3 \%$ in pigs. Few studies of taeniasis/cysticercosis were undertaken in Bali prior to a series of research programs commenced since the 1990s. Both TAENIA SAGINATA and T. solium continue to be endemic in Bali. Molecular studies have revealed that all T. SAGINATA-like tapeworms detected in Bali are T. SAGINATA. No evidence has been found for the presence of TAENIA ASIATICA in Bali. Economic, sanitary and education improvements across much of the island over the past decades have been associated with a decline in the amount of transmission of $T$. solium such that

the parasite now seems to be restricted to the eastern part of the island, a small area on the northeastern slope of Mt. Agung, the highest mountain in Bali. The living environment including sanitation and hygiene condition in this endemic area remains relatively poor especially during the half-year dry season, and pigs continue to roam freely. In this review, historical records and ongoing projects towards elimination of taeniasis/cysticercosis in Bali are reviewed to provide a better understanding of the present situation of taeniasis/cysticercosis in Bali towards a future, cysticercosis-free tropical resort island.
\end{abstract}

\section{Introduction}

The term taeniasis/cysticercosis refers to infections in the definitive and intermediate hosts, respectively, of a number of species of taeniid cestode parasite of the genus TAENIA. Humans act as definitive hosts for three species - TAENIA solium, TAENIA SAGINATA and TAENIA ASIATICA, with typical intermediate hosts being pigs, cattle and pigs, respectively (Ito and Budke, 2014; Ito et al., 2003).

Indonesia has long been known to be endemic for both T. solium and T. SAGINATA (Bonne et al., 1940; De Seze et al., 1938). Recognition of $T$. solium in Bali was highlighted by its being identified as the source of the introduction of the parasite into West Papua (= former Irian Jaya)

\footnotetext{
* Corresponding author.

${ }^{* *}$ Corresponding author.

E-MAIL ADDRESSES: psutisna@yahoo.com (P. Sutisna), akiraito@asahikawa-med.ac.jp (A. Ito).
} 
Received 22 September 2018; Received in revised form 27 October 2018; Accepted 27 October 2018 Availableonline290ctober 2018

OOO1-706X/@2018ElsevierB. V. Allrightsreserved. 
following a gift from Indonesian President Soeharto of pigs from Bali to the Ekari people who were apparently uncertain whether to support Papua becoming part of Indonesia in the United Nations-directed "Act of Free Choice' held in 1969 (Desowitz, 1981). In 1973, Tumada and Margono identified almost $10 \%$ of people living in the Paniai highlands as having taeniasis (Tumada and Margono, 1973a, 1973b), shortly after which Tumada, Subianto and their colleagues (Gajdusek, 1978; Subianto et al., 1978; Tumada and Subianto, 1974) described severe burns in neurocysticercosis patients from West Papua. More recent epidemiological studies have delineated the extent of $T$. solium transmission in West Papua (Ito et al., 2002, 2003, 2004, 2005a, 2005b, 2014; Margono et al., 2001a, 2001b, 2003, 2005, 2006; Salim et al., 2009; Subahar et al., 2001; Swastika et al., unpublished; Wandra et al., 2000, 2003; Widarso et al., 1999, 2001), in Papua New Guinea (Fritzsche et al., 1990; Ito et al., 2004; McManus, 1995; Owen, 2006), and on the island, Bali (see below), and are also beginning to unravel the epidemiology of T. SAGINATA and T. ASIATICA in Bali and elsewhere in Indonesia.

The island of Bali is one of the 33 provinces of Indonesia, located in the tropics at $115^{\circ} 42^{\prime}$ East by $8^{\circ} 50^{\prime}$ South, with an area of about 5,600 km² (Sutisna et al., 1999) (Fig. 1). In 2015 Bali's population was recorded to be 4.15 million (Center for Statistical Data of Bali Province, 2015, unpublished data), the majority $(93.4 \%)$ of whom are followers of the Hindu religion, with the remainder being Muslim, Christian, Buddhist, and others (Wandra et al., 2007a, 2007b). Administratively, Bali is divided into eight districts: Buleleng, Jembrana, Tabanan, Ba- dung, Gianyar, Bangli, Klungkung and Karangasem; Denpasar is the capital city, located in Badung district (Center for Statistical Data of Bali Province, 2015) (Fig. 1). Approximately $80 \%$ of Bali's population lives in rural areas where personal and environmental hygiene, particularly human fecal disposal sanitation, is generally not adequate (Sutisna, 1989, 1998, 2001, 2002; Sutisna et al., 1999; Theis et al., 1994; Wandra

et al., 2011, 2015; Waruju, 1988; Widjana and Kapti, 1983).

Most of the Indonesian population is Muslim (87.18\%) (Wandra et al., 2013). As taeniasis in humans caused by T. solium is transmitted through eating infected pork, religious restrictions on the keeping of pigs and eating pig meat have limited the national impact of $T$. solium in most of Indonesia (Margono et al., 2002, 2005). Exceptions include Papua (former Irian Jaya) where the much of the local population is Christian (Coker-Vann et al., 1981, 1984; Desowitz et al., 1977; Diwan et al., 1982; Gajdusek, 1977; Gunawan et al., 1975; Salim et al., 2009; Simanjuntak et al., 1977, 1997; Subianto et al., 1978; Theis et al., 1994; Tumada and Margono, 1973a, 1973b; Wandra et al., 2000, 2003; Widarso et al., 1999, 2001) and Bali where the majority of the popu- lation is Hindu.

Cysticercosis in pigs and cattle was reported in Indonesia as long ago as 1928 in the doctoral thesis of Le Coultre (1928) from the Rijksuniversiteit te Utrecht. While Le Coultre referred to the presence of both cattle and pig cysticercosis from several different Indonesian islands, most original research data that he obtained came from Bali, where cysticerci were found in $20-30 \%$ of cattle and $2-3 \%$ of pigs. Other than a small number of reports concerning neurocysticercosis in patients from Bali, during the long period between Le Coultre's study and the 1990's, there is little other information about taeniasis/cysticercosis in Bali (Tables 1-3) except a government Veterinary Bulletin (Anonymous, 1974-1977), and Simanjuntak et al. (1977). The continued presence of $T$. solium in Bali was suggested by Desowitz et al. (1977) and Diwan et al. (1982) who indicated that the T. solium cysticerci which they used for preparation of diagnostic antigens were collected from pigs in Bali.

During the 1990 collaborative projects were established between Udayana University in Bali and both Salford University, UK (19951997) and Asahikawa Medical University, Japan (2002-present). The first of these projects aimed to provide training for staff of Department of Parasitology, Faculty of Medicine, Udayana University on ELISA, 
coproantigen techniques for diagnosis of taeniasis/cysticercosis. The training was carried out in the UK followed by a joint study on taeniasis/cysticercosis in Bali (Sutisna et al., 1999). The second project aimed mainly to carry out joint epidemiological studies on the transmission of taeniasis/cysticercosis in Bali with transfer of serological and molecular technologies to the staff of the same department at Udayana University (Ito et al., 2000, 2005a). An aim of the Japanesesponsored program was the establishment of a Research and Reference Center for taeniasis/cysticercosis in Indonesia, with a longer-term goal of elim- ination of $T$. solium taeniasis/cysticercosis from Bali, and towards the control of taeniasis/cysticercosis in West Papua and Papua New Guinea. It has been revealed that the endemic areas of $T$. solium taeniasis/cy- sticercosis in Bali are restricted principally, if not entirely, to the northeastern slope of Mt. Agung (Swastika et al., 2012, 2016, 2017; Wandra et al., 2015) (Fig. 1).

\section{Origins of Taenia species in Bali}

There is no clear evidence about when $T$. SAGINATA or $T$. solium may have been introduced to Indonesia, or to Bali in particular. The Indonesian islands have a history of habitation by hominids for hun- dreds of thousands of years (Brown et al., 2004; Heinsohn, 2001). In- digenous hunter-gatherer communities in Indonesia are believed to have been replaced by farming communities during the Austronesian expansion into the Pacific and Indonesia, sometime after about 4,000 years BC (Bellwood et al., 2006). These groups had a well-established domestication of several animal species, including pigs and dogs. However, the Indonesian Islands have several indigenous suid species and the banteng, Bos JAVANICUS (Groves, 2006; Heinsohn, 2001), which could have provided hosts for TAENIA species transmitted by early ho- minins or modern humans over a substantially longer period than only the last 6,000 years.

Outside Indonesia, T. SAGINATA and $T$. solium have a long evolu- tionary history with hominids. Both species are considered to have evolved from parasites of carnivores and independently underwent host switching to humans as definitive hosts (de Queiroz and Alkire, 1998). This event is believed to have occurred prior to the development of agriculture and animal domestication (Hoberg et al., 2001). Evidently, host switching reoccurred in $T$. SAGINATA in Asia, leading to the sister species T. ASIATICA which prefers parasitising the liver of pigs in its metacestode stage. Both T. SAGINATA and T. solium have been recorded from several wild bovid and suid species, respectively (Abouladze, 1964), and it seems likely that human taeniasis travelled with humans out of Africa. T. solium evolved into distinct genotypes in Asia and Africa (Nakao et al., 2002). In relation to these parasites infecting do-

mestic livestock species, cattle are believed to have been domesticated from Aurochs in two independent events, one occurring approximately 10,500 years ago in the region of Anatolia and Iraq in the Near East (Bollongino et al., 2012; Loftus et al., 1994) and the other at least 7,000 years ago in South Asia (Bradley et al., 1998; Loftus et al., 1994). Old- World and New-World suids diverged approximately 35 million years ago and a variety of species have been, and remain, endemic in the islands of south-east Asia. Sus SCROFA was domesticated independently in or around Anatolia approximately 10,000 years ago, and in China about 8,000 years ago (Frantz et al., 2016).

It is possible that human-transmitted TAENIA have been present in Indonesia for at least 40,000 years, if not considerably longer. The presence of early hominids as well as native bovine and suid species in Indonesia raise the possibility that the presence of TAENIA species may have pre-dated the arrival of Austronesian farmers into the region. In- depth genotyping of TAENIA from Indonesia may shed light on whether the parasites currently present in Indonesia may have been present for a long period and isolated from other ôld-World parasite populations, or possibly arrived with the Austronesian expansion or more recently. 


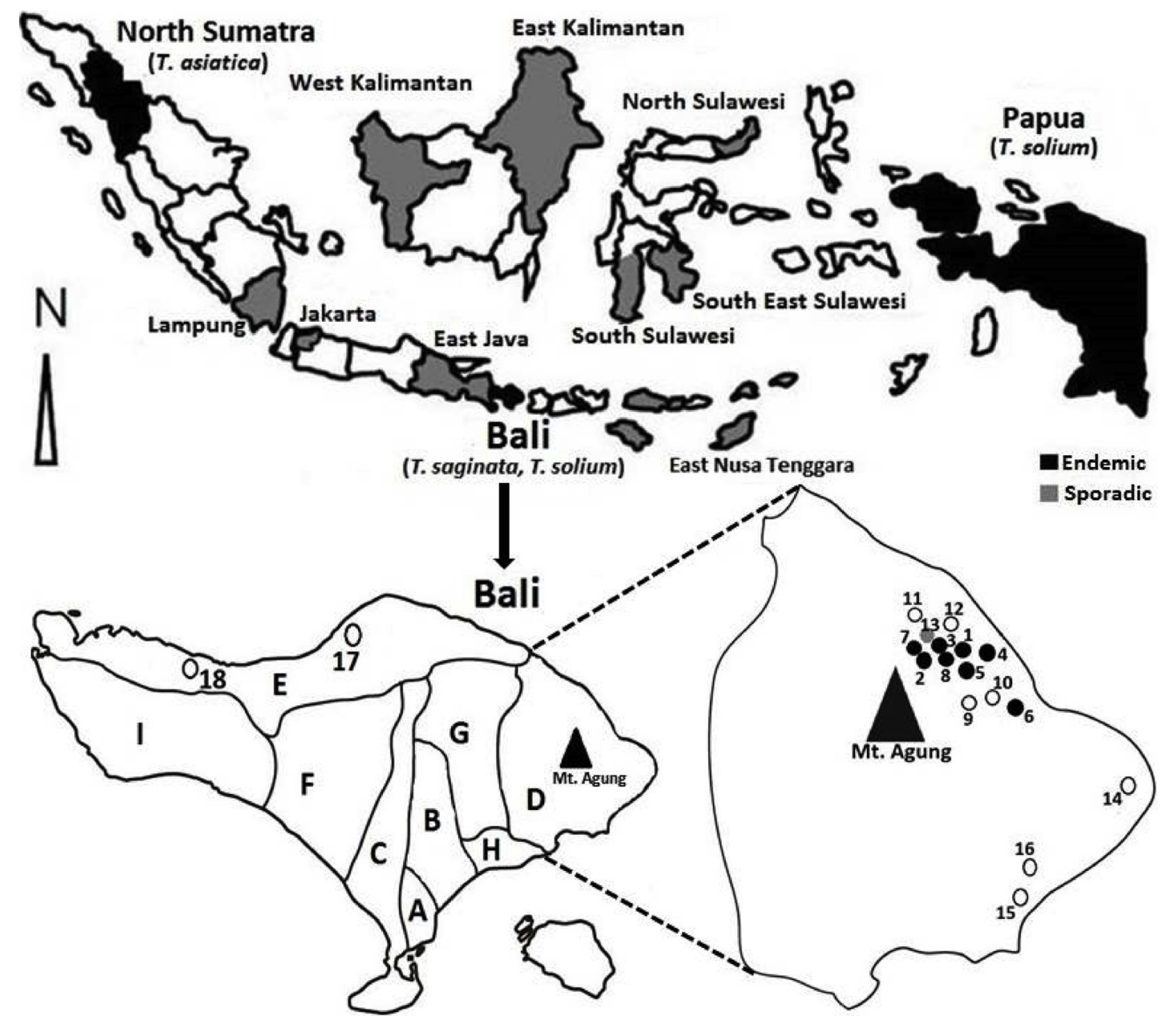

Fig. 1. Map of Indonesia showing the endemic situation on $T$. solium cysticercosis (from Wandra et al., 2013) and Bali with the updated data (from Wandra et al., 2013; Swastika et al., 2016, 2017, unpublished data). Indonesian map shows T. solium endemic areas and sporadic data are deposited with T. ASIATICA in North Sumatra where T. solium is rare so far as we know, and both T. SAGINATA and T. solium coendemic in Bali are stressed on the map. All other areas either sporadic or endemic are indicating $T$. solium. A-I are 9 districts in Bali: Denpasar, Gianyar, Badung, Karangasem, Buleleng, Tabanan, Bangli, Klungkung and Jembrana, respectively. Denpasar is the capital city of Bali. Taeniasis of $T$. SAGINATA is not rare or rather common in Denpasar, Gianyar, Badung close to Denpasar. It may be affected higher income and people prefer to eat "beef LAWAR". Taeniasis/cysticercosis of $T$. solium is exceptionally endemic in the mountainous rural area in Karangasem. However, the endemic area is focal and located on the northeastern slope of Mt. Agung: Numbers of 1-13 in Karangasem (see Swastika et al., 2016). So far as we have examined a total of 13 Banjars (Br.) on the northeastern slope of Mt. Agung (Br. Pangeno (1), Br. Batugiling (2), Br. Bahel (3), Br. Batudawa Kelod (4), Br. Batudawa Kaja (5), Br. Bingin (6), Br. Bhuana Kusuma (7), Br. Pandan Sari (8), Br. Pule Samuh (9), Br. Ulun Desa (10), Br. Bantas (11), Br. Juntal Kelod (12) and Br. Tegal Panti (13)). T. solium carriers have been confirmed from (1) - (8) (shown in closed circles), whereas no carrier was confirmed from (9) (12) (in open circles). One T. solium taeniasis carrier confirmed in Gianyar 2016 was born and lived in (13) shown in Karangasem. Br. Bugbug (14), Br. Seraya (15) and abattoir in the City, Amlapura (16), all pigs examined are free of $T$. solium. Singaraja in Buleleng district (17) was the Capital city of Bali from 1849 until 1959. In Buleleng, no one remembers $T$. solium cysticerci in pigs over the past two decades. Living environment in the mountainous areas in Gerokgak (18) appears much better with running water supply even during the dry season.

\section{Food habits of Balinese people in relation to taeniasis}

beef. Both "pork

Balinese people are fond of eating "LAWAR", a local traditional food made of raw minced pork or beef, mixed with grated coconut, spices, vegetables (usually chopped boiled young jackfruit or long bean) and raw blood. "Pork LAWAR" is commonly prepared and consumed collectively during religious ceremonies in each community or by members of households on Balinese holydays. It is also sold daily in many food stalls (Fig. 2a, b). On the other hand, "beef LAWAR" does not form part of the typical diet consumed by Hindu, nevertheless it is sold in food stalls (Margono et al., 2001b, 2005; Sutisna, 1989, 2002; Swastika et al., 2017; Wandra et al., 2006a, 2011). "Beef LAWAR" is more popular in urbanized or semi-urbanized areas in Bali, whereas "pork $L A W A R$ " is popular all over Bali. Recent trends in preparation of "pork LAWAR" are using boiled pork (Fig. 2b) rather than uncooked pork (Fig. 2a), whereas "beef LAWAR" continues to utilize uncooked 
LAWAR" and "beef LAWAR" have 2 types, namely "LAWAR BARAK" (red Lawar) made of raw pork or beef with fresh blood, and "LAWAR putih" (white Lawar) made of well-grilled pork or beef with no blood.

In addition to "LAWAR", another traditional dish called "Komoh" used to be very popular especially in Buleleng district where the former capital city, Singaraja, is located (Fig. 1). Singaraja was founded by the King Anak Agung Panji Sakti on 30 March 1604. In its original version, "Komoh" was made of chopped raw pig liver mixed with spices, then added with water-diluted fresh blood to make it like soup (Fig. 2c). This special dish used to be eaten together with "LAWAR" and other tradi- tional dishes during community ritual celebrations. Unlike "LAWAR" which remains very popular for most Balinese people until today, "Komoh" now is less frequently made as in the past, possibly due to people's increasing awareness of some possible health hazards from raw blood. In "Komoh", large amount of raw blood is used as the main in- gredient to make soup. It is different from "pork LAWAR" which uses a 
Table 1

Prevalences of taeniasis reported based on field surveys in Bali, Indonesia.1978-2004.

\begin{tabular}{|c|c|c|c|c|}
\hline Year & Area surveyed & Prevalence of taeniasis (\%) & Methods & Reference \\
\hline \multirow[t]{4}{*}{1978} & Trunyan Village, Bangli District & $0.8(1 / 131)$ & Formalin-ether & Rasidi et al. (1979) \\
\hline & \multicolumn{2}{|l|}{ Sukawati Village, Gianyar District } & & \\
\hline & \multirow[t]{2}{*}{ Padangsambian Village, Denpasar District } & $1.0(2 / 199)$ & & \\
\hline & & $3.4(7 / 208)$ & & \\
\hline 1982 & Abiansemal Sub-district, Badung District & $2.0(52 / 2,538)$ & Anamnesis & Widjana and Kapti (1983) \\
\hline 1982 & Penatih Village, Badung District & $23.0(41 / 178)$ & Anamnesis, direct smear & Bakta and Soewarno (1983) \\
\hline 1987-1988 & Banjar Kelod, Renon Villages, Denpasar District & $7.1(37 / 515)$ & Anamnesis, formalin-ether, perianal swab & Sutisna (1990) \\
\hline \multirow[t]{2}{*}{ 1994-1995 } & Pamesan, Ketewel Villages, Gianyar District & $1.29(2 / 155)$ & Direct smear, coproantigen- ELISA & Sutisna et al. (1999) \\
\hline & Batuaji, Batubulan Villages, Gianyar District & $1.43(1 / 70)$ & & \\
\hline 2002 & $\begin{array}{l}\text { Penarukan, Kerambitan Villages, Tabanan District } \\
\text { Ketewel Village, Gianyar District }\end{array}$ & $\begin{array}{l}0(0 / 190) \\
25.6(32 / 125)\end{array}$ & Anamnesis, direct smear & Wandra et al. (2006a) \\
\hline \multirow[t]{3}{*}{2004} & Ketewel Village, Gianyar & $27.5(14 / 51)$ & Anamnesis, direct smear & Wandra et al. (2006a) \\
\hline & District Jagapati Village, & $1.1(1 / 94)$ & & \\
\hline & $\begin{array}{l}\text { Badung District Penatih Village, } \\
\text { Badung District }\end{array}$ & $7.0(9 / 128)$ & & \\
\hline
\end{tabular}

small amount of fresh blood just enough to mix minced pork, grated coconut to give the red color and specific flavor. Today, people make "Komoh" without raw blood but either of chopped pig's liver, pork, beef, chicken or sliced skin, mixed with spices and water or meat broth, then all boiled. "Komoh" is normally eaten with "LAWAR", "SATE", and other dishes during ritual events. When it was made of raw or under cooked material, the liver without any other viscera were used with raw blood.

\section{History of the studies on taeniasis/cysticercosis in Bali}

For reason of simplicity, we outline this brief account of the "history" into three main sections: 1) studies on taeniasis, 2) studies on cysticercosis and 3 ) perspectives or ideas towards the establishment of a program for prevention and control of taeniasis/cysticercosis in Bali.

\subsection{Studies on TAENIASIS in BALI}

Prevalences of taeniasis based on field surveys in Bali from 1978 until 2004 are summarized in Table 1. In another report, Wandra and co-workers (Wandra et al., 2015) summarized that results of field surveys done in the period of 2002 to 2014 covering all eight districts of Bali revealed that taeniasis cases had been detected from four locations namely Denpasar and the districts of Badung, Gianyar and Karangasem, but no cases were found in the other 5 districts i.e. Bangli, Tabanan, Jembrana, Klungkung, Buleleng.

Table 2

\subsection{Species IDENTIFICATION}

\subsubsection{Taenia solium $v s$ Taenia saginata}

Field surveys that have involved the recovery of tapeworms from taeniasis patients have allowed differentiation of the worms as being either T. solium or T. SAGINATA or T. ASIATICA. Early studies, such as those of Bakta and Soewarno (1983), Koesharjono et al. (1987), Sutisna (1990), all in Bali, and Cross et al. (1976), Depary (2000, 2003), Depary

and Kosman (1991), Fan et al. (1988, 1989, 1990a, 1992), Kosin et al. (1972, 1988), Kosman et al. (1988), all in Samosir Island, North Su- matra, were unaware at the time of the existence of T. ASIATICA.

Identification of the species was based on morphology of gravid proglottids i.e. the number of lateral main uterus branches or the pre- sence/absence of an armed rostellum on the scolex. For this reason, these T. SAGINATA-like worms were diagnosed as being T. SAGINATA. In Bali, Bakta and Soewarno (1983) examined 9 TAENIA worms and iden- tified 8 T. SAGINATA and 1 T. solium. Koesharjono et al. (1987) examined 54 TAENIA worms and identified all were T. SAGINATA. Sutisna (1990) examined 38 TAENIA worms in a study in Renon in Denpasar city and identified 37 T. SAGINATA and 1 T. solium. In another field survey in Banjar Pamesan, in Ketewel subdistrict, and Banjar Batuaji in Batubulan subdistrict in Gianyar district, Sutisna et al. (1999) examined 3 TAENIA worms and identified $2 \mathrm{~T}$. SAGINATA and $1 \mathrm{~T}$. solium (Table 1). More re- cent studies have employed molecular techniques, allowing differentiation between T. SAGINATA AND T. ASIATICA. Wandra et al. (2015) un- dertook epidemiological surveys in the eight districts of Bali, and in

Data of seroprevalences of cysticercosis reported in humans and pigs in Bali, Indonesia.1981-2016.

\begin{tabular}{|c|c|c|c|c|}
\hline Year & Place/District & Human & Pig & Reference \\
\hline 1981 & Tenganan/Karangasem & $20.8 \%(11 / 53)$ & NS & Coker-Vann et al., 1981 \\
\hline 1994 & All over Bali & $12.6 \%(94 / 746)$ & NS & Theis et al., 1994 \\
\hline 1998 & Pamesan/Gianyar & $5.2 \%(6 / 115)$ & NS & Sutisna et al.,1999 \\
\hline 2002-2013 & Gianyar & $2.7 \%(12 / 445)$ & NS & Wandra et al., 2015 \\
\hline 2014 & Gianyar & $7.1 \%(1 / 14)$ & NS & Swastika et al., unpublished data \\
\hline 2004 & Badung & $0.0 \%(0 / 91)$ & NS & Wandra et al., 2015 \\
\hline $2004-2010$ & Denpasar & $0.0 \%(0 / 119)$ & NS & Wandra et al., 2015 \\
\hline 2007 & Bangli & $0.0 \%(0 / 32)$ & NS & Wandra et al., 2015 \\
\hline 2008 & Tabanan & $0.0 \%(0 / 42)$ & NS & Wandra et al., 2015 \\
\hline 2008 & Jembrana & $0.0 \%(0 / 84)$ & NS & Wandra et al., 2015 \\
\hline 2009 & Klungkung & $0.0 \%(0 / 100)$ & NS & Wandra et al., 2015 \\
\hline 2009 & Buleleng & $0.0 \%(0 / 47)$ & NS & Wandra et al., 2015 \\
\hline 2006 & Karangasem (urban) & $2.8 \%(1 / 36)$ & NS & Wandra et al., 2015 \\
\hline 2011-2013 & Karangasem (rural) & $5.3 \%(27 / 507)$ & $13.1(43 / 329)$ & Wandra et al., 2015 \\
\hline 2014 & Karangasem & $4.2 \%(5 / 118)$ & NS & Swastika et al., unpublished data \\
\hline 2015 & Karangasem & $1.9 \%(4 / 207)$ & NS & Swastika et al., unpublished data \\
\hline 2016 & Karangasem & $3.1 \%(6 / 193)$ & NS & Swastika et al., unpublished data \\
\hline
\end{tabular}


Table 1

NS: No samples. 
Table 3

Summarized data of cysticercosis in Bali, 1974-2010 (NCC: neurocysticercosis, DCC: disseminated cysticercosis, and OCC: ocular cysticercosis)

\begin{tabular}{|c|c|c|c|c|}
\hline $\begin{array}{l}\text { Year/ } \\
\text { References }\end{array}$ & $\begin{array}{l}\text { Hospital }(\mathrm{H}) \text { or area/ } \\
\text { number of cases/ } \\
\text { ethnicity }\end{array}$ & Diagnosis & Methods of examination & Main symptoms \\
\hline 1974/Ngoerah (1975) & $\begin{array}{l}\text { Wangaya } \mathrm{H} / 4 \text { cases/ } \\
3 \text { Balinese } 1 \\
\text { Chinese }\end{array}$ & DCC & $\begin{array}{l}\text { X-ray, } \\
\text { anatomical pathology }\end{array}$ & $\begin{array}{l}\text { epileptic seizures, } \\
\text { meningeal irritation, } \\
\text { subcutaneousand cutaneous nodules }\end{array}$ \\
\hline $\begin{array}{l}\text { 1995-1997/ } \\
\text { Sudewi and Nuartha (1998) }\end{array}$ & $\begin{array}{l}\text { Sanglah } \mathrm{H} / 25 \\
\text { cases/ all Balinese }\end{array}$ & NCC & CT Scan & $\begin{array}{l}\text { epileptic seizures, } \\
\text { headaches, unconsciousness }\end{array}$ \\
\hline $\begin{array}{l}\text { 2003-2005/ } \\
\text { Sudewi et al. (2008) }\end{array}$ & $\begin{array}{l}\text { Sanglah } \mathrm{H} / 5 \text { cases/ } \\
\text { all Balinese }\end{array}$ & $\begin{array}{l}\mathrm{DCC}(1) \\
\operatorname{NCC}(4)\end{array}$ & $\begin{array}{l}\text { CT Scan, } \\
\text { anatomical pathology }\end{array}$ & $\begin{array}{l}\text { epileptic seizures, } \\
\text { headaches, unconsciousness, } \\
\text { subcutaneous nodules (DCC) }\end{array}$ \\
\hline 2004/Wandra et al. (2011) & $\begin{array}{l}\text { Gianyar } / 3 \text { cases/ } \\
\text { all Balinese }\end{array}$ & NCC & CT Scan, serology & $\begin{array}{l}\text { epileptic seizures, headaches, unconsciousness (2), } \\
\text { subcutaneous nodules (1) }\end{array}$ \\
\hline 2007/Wandra et al. (2016) & $\begin{array}{l}\text { Gianyar } / 1 \text { case/ } \\
\text { Balinese }\end{array}$ & $\begin{array}{l}\text { NCC in } T . \text { SAGINATA taeniasis } \\
\text { case }\end{array}$ & CT Scan, serology & epileptic seizures after $\mathrm{PZQ}{ }^{*}$ treatment for $T$. SAGINATA \\
\hline $\begin{array}{l}\text { 2009/Sudewi et al. } \\
\text { (unpublished) }\end{array}$ & $\begin{array}{l}\text { Sanglah } \mathrm{H} / 8 \text { cases/ } \\
\text { all Balinese }\end{array}$ & NCC & CT Scan, serology & epileptic seizures, headaches, unconsciousness \\
\hline 2010/Swastika et al. (2012) & $\begin{array}{l}\text { Indera } \mathrm{H} / 1 \text { case/ } \\
\text { Balinese }\end{array}$ & OCC & $\begin{array}{l}\text { Anatomical pathology, } \\
\text { mtDNA, serology }\end{array}$ & redness, swelling, pain, cyst in the left eye \\
\hline 2010/Wandra et al. $(2015)^{\#}$ & $\begin{array}{l}\text { Gianyar } / 3 \text { cases/ } \\
\text { all Balinese }\end{array}$ & $\begin{array}{l}\operatorname{NCC}(1)^{\S} \\
\text { Cysticercosis }(2)^{\pi} \\
\text { in } T . \text { SAGINATA taeniasis cases }\end{array}$ & Serology, CT Scan & asymptomatic \\
\hline
\end{tabular}

"Praziquantel.

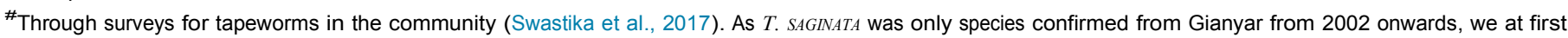

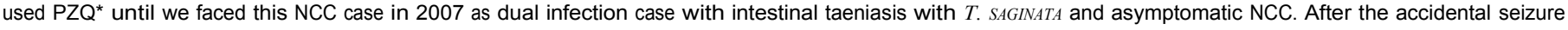
attack caused after $P Z Q$ treatment was confirmed, we stopped using $P Z Q$ and used niclosamide.

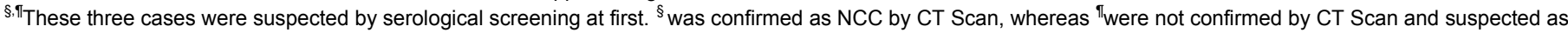
cysticercosis but not NCC.

Denpasar city, during 2002-2014 and examined 129 tapeworms ex- pelled from 129 tapeworm carriers by mitochondrial DNA (mtDNA). The results confirmed all tapeworms identified in the study were T. SAGINATA.

In contrast, in surveys carried out in 2011-2014 in a rural remote area of Kubu sub-district on the northeastern slope of Mt. Agung in Karangasem district of Bali, they obtained a total of 13 tapeworms from 13 tapeworm carriers, and they all were identified as the Asian geno- type of $T$. solium by the same molecular technique (Wandra et al., 2015). The data revealed that all taeniasis cases either by $T$. SAGINATA $(\mathrm{n}=129)$ or $T$. solium $(\mathrm{n}=13)$ were solitary cases. Additional cases have been recorded until 2017 and discussed below (Swastika et al., unpublished).

\subsubsection{Taenia asiatica}

TAENIA ASIATICA is considered a sister species of T. SAGINATA based on mitochondrial gene analysis (Bowles and McManus, 1994; Eom and Rim, 1993; Fan, 1988; Fan et al., 1988; Hoberg et al., 2000; Ito et al., 2003; McManus and Bowles, 1994; Simanjuntak et al., 1997; Zarlenga et al., 1991), with the two species being morphologically similar with the exception of the presence of rostellum in the scolex of T. ASIATICA
(Fan, 1988; Fan et al., 1988). The life cycles of the parasites differ with the predominate intermediate host (pig vs cattle) and organ tropism (viscera vs muscle). However, recent molecular studies on $T$. ASIATICA which have included both mitochondrial and nuclear gene analyses have revealed that many T. ASIATICA circulating in Asia, including Sa- mosir Island in Indonesia, Thailand, Vietnam, Lao PDR, China and Korea do not correspond to the pig transmitted T. ASIATICA described originally from Taiwan. Instead, these are hybrid-derived descendants of T. ASIATICA and T. SAGINATA (Okamoto et al., 2007, 2010; Yamane et al., 2012, 2013). The intermediate host preference and tissue tropism for the cysticerci of these hybridderived descendants has not yet been confirmed; the local people's life style which includes eating uncooked pig viscera, but no beef, suggest that pigs are likely to be the inter-mediate host (Zein et al., 2019).

Only T. ASIATICA taeniasis, caused by hybrid-derived descendants of T. ASIATICA and T. SAGINATA (Yamane et al., 2013), has been reported in residents of Samosir Island located in Lake Toba, Samosir district, North Sumatra, Indonesia (Cross et al., 1976; Fan et al., 1988; Kosin et al., 1972, 1988). Kosin et al. (1972) reported 9.5\% of 285 stool specimens examined in Samosir Island were egg and/or proglottids positive, and proglottids appeared to be similar to T. SAGINATA. Depary and Kosman
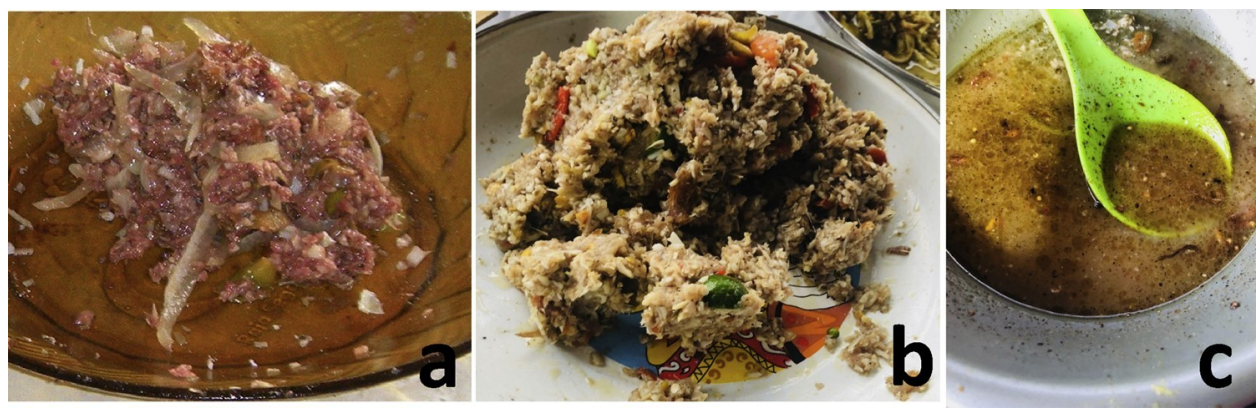

Fig. 2. Lawar (s) at a Lawar stall in Gianyar district taken in January 2011 by Al, and Lawar (b) and Komoh (c) at another Lawar stall in Gianyar taken in October 2018 by Indah Budi Apsari. 
P. SUTISNA et $A L$.

(1991) noted the contradiction that T. SAGINATA (or, as we now know, $T$. SAGINATA-like tapeworms) exists in communities on Samosir Island where people ate pork, dog, sheep or goat, but very rarely ate beef. From 1972 onwards until 2016, T. SAGINATA (=T. ASIATICA) surveys were exclusively conducted on Samosir Island (Cross et al., 1976; Fan et al., 1988, 1989, 1990a, 1992; Kosin et al., 1988; Kosman et al., 1988; Suroso, 2000; Suroso et al., 2006; Wandra et al., 2006b, 2007a, 2007b). Similarly, in Bali a paradoxical situation exists where Balinese people consume "pork LAWAR" more frequently than "beef LAWAR", taeniasis caused by T. SAGINATA is found more frequently than taeniasis caused by

T. solium.

Dharmawan et al. (1993) examined 638 pigs slaughtered in Den- pasar abattoir in 1993 and found yellowish and whitish spots on the livers of 146 pigs (22.8\%), numbering 1-6 spots in each of the infected livers, but almost all the cysts were in degenerative or calcified con- dition. They found only one mature cyst in one pig's liver. Microscopy showed the specific features of a scolex with hooklets. Based on this observation, they suspected that the cystic forms in the pigs' livers were likely cysticerci of $T$. SAGINATA TAIWANENSIS (later re-named $T$. ASIATICA), however there was no evidence to indicate these degenerative lesions were caused by a cestode parasite. Furthermore, the single viable cy- sticercus was identified as being TAENIA HYDATIGENA. Two years later, with a similar objective Dharmawan (1995) undertook an experimental study by administering gravid proglottids identified morphologically as T. SAGINATA (obtained from treated Balinese patients) to four groups of healthy male Bali pigs (total 33 pigs) and two cattle. Results of post mortem examinations done after the experimental infections found only a single viable cysticercus in the pigs, being in the liver, and numerous degenerative or calcified lesions, also in the liver. The two cattle however had numerous viable cysticerci but only in muscle tissue (Dharmawan, 1995). These findings are similar to those of Fan and colleagues (Fan et al., 1990a, 1990b, 2006) who found that pigs ex-perimentally infected with $T$. SAGINATA of Ethiopian origin developed numerous non-viable cysts in the liver as well as a small number of viable cysticerci (Fan et al., 1990b), whereas experimental infection of pigs with T. ASIATICA led to the development of often large numbers of viable cysticerci in the liver (Fan et al., 1990a). It seems likely that the investigations undertaken by Dharmawan and colleagues were prob- ably involved T. SAGINATA rather than $T$. ASIATICA. Since no molecular

examination was done in these studies, it was realized that no conclusive confirmation could yet be made regarding the TAENIA species involved.

As mentioned above, mitochondrial DNA analysis of all T. SAGINATAlike tapeworms in Bali revealed all of them as T. SAGINATA (Wandra et al., 2007a, 2007b, 2015). The absence or low prevalence of $T$. ASIATICA in Bali may be associated with a drastic reduction in the popularity of "Komoh" in its original style with "raw liver in the soup of raw blood of pigs". A report by Yamasaki et al (2004) which referenced a specimen of $T$. ASIATICA derived from Bali was in error - the sample specimen actually came from Samosir Island (Yamasaki $\mathrm{H}$, personal commu- nication).

While T. ASIATICA is rare or non-existent in Bali, this species is present elsewhere in Indonesia including Samosir Island (Fan et al., 1988, 1989, 1990a, 1992; Margono et al., 2005; Wandra et al., 2006b, 2013). Most recently, Zein et al. (2019) reported 171 T. SAGINATAlike tapeworm carriers in several sub-districts, Simalungun district, North Sumatra, which locates eastern side of Lake Toba in 2017. Four specimens were provided for molecular confirmation to their Japanese collaborators. They all were confirmed to be T. ASIATICA by mitochondrial $\operatorname{cox} 1$ gene analysis. Nuclear gene analysis successful with only two of them re- vealed that they were hybrid-derived descendants of $T$. ASIATICA and T. SAGINATA completely same as those in Samosir Island. Samosir Island and Simalungun district are adjacent in North Sumatra (Zein et al., 2019).

The newly confirmed endemic areas are in the large palm farms, and
ActATropicA $190 \mathrm{C}$ the living environment appears to be very poor. The extent of the area in Sumatra that is endemic for T. ASIATICA other than Samosir Island 
(Cross et al., 1976; Fan et al., 1988; Kosin et al., 1972, 1988; Margono et al., 2005; Suroso et al., 2006; Wandra et al., 2006b, $2007 a, 2007 b, 2013$ ) is unclear; there have been no studies other than that of Zein et al. (2019) in the past 5 decades. Additional surveys in poorer villages in North Sumatra may reveal more cases. Clearly, there is potential for the further spread of $T$. ASIATICA through the travel or migration of TAENIA carriers to areas of Indonesia where the presence of pigs and poor sanitary conditions would favor introduction of the parasite.

\subsubsection{The number of TAPEWORMS in BALINESE TAENIASIS PATIENTS}

Cases of multiple tapeworms infecting people have been reported to be not rare in many other Asian countries (e.g. Anantaphruti, 2005; Arambulo et al., 1976; Cabrera, 1965; Chung and Bruce, 1976; Fan et al., 1990c; Ito et al., 2013; Lee et al., 1966; Pawlowski and Schultz, 1972; Tesfa-Yohannes, 1990). In contrast, our data from studies in Bali have revealed a different pattern. No multiple tapeworm infections have been encountered by Bakta and Soewarno (1983), Sutisna (1990) and Sutisna et al. (1999). Also, results of treatment of taeniasis carriers performed in field surveys carried out over more than a decade between 2002-2017 in Gianyar, Karangasem and other districts of Bali showed that of a total of 170 taeniasis carriers who expelled tapeworms after treatment, 150 expelled only a single tapeworm of $T$. SAGINATA, whereas 20 including 2 cases with two tapeworms each, all of which were T. solium. So, a total of 18 T. solium cases were solitary cases (Swastika et al., 2017; Swastika et al., unpublished; Wandra et al., 2015). We

conclude that infections with multiple TAENIA tapeworms, either $T$. SAGINATA or $T$. solium are very rare in Bali. It appears to be crucially dif- ferent from China where $\geq 20 \mathrm{~T}$. solium worms have been often con- firmed in each patient (Ito et al., 2013; Li et al., in prep.) and many other Asian countries mentioned above.

One most possible explanation for the infrequency of cases of multiple tapeworm infections in Bali may be that while the Hindu community undertakes home slaughtering of pigs, they are

infected with the eggs released from themselves.

In later years with the introduction of modern serological techniques, researchers began to employ ELISA and immunoblot techniques in their studies to detect cysticercosis in people and animals in Bali (Ito et al., 2004). The first published report of serologic survey on cysticercosis in Bali was made by Coker-Vann et al. (1981) who found a $20.7 \%$ seroprevalence of anti- $T$. solium cysticercus antibodies in Tenganan village, Manggis subdistrict, Karangasem district. Theis et al. (1994) examined by immunoblot (EITB) and ELISA techniques 746 serum samples of asymptomatic people and 74 serum samples of people with epilepsy collected from all over Bali and found seropositivity for antibodies to T. solium cysticercus of $12.6 \%$ and $13.5 \%$, respectively. Sutisna et al. (1999) using EITB technique (carried out at Salford Uni- versity, UK) examined 115 serum samples collected in a study in Banjar Pamesan, Ketewel village, Gianyar district, and found a $5.2 \%$ (6/115) seropositivity for anti-T. solium cysticercus antibodies. Wandra et al. (2015) examined 1,489 serum samples collected in community surveys carried out during 20022014 by ELISA (undertaken at Asahikawa

Medical University, Japan) and found seroprevalence of anti- $T$. solium cysticercus antibodies of $2.7 \%(13 / 443)$ in Gianyar district, $2.8 \%$ (1/ 36 ) in urban Karangasem, and 5.3\% (27/507) in rural Karangasem district, but no positive serology response was detected in people in Denpasar city and six other districts (Buleleng, Jembrana, Tabanan, Badung, Bangli, Klungkung) (see Table 2). Although it is impossible to compare these serological data on the same standard, the tendency in seropositivity revealed Karangasem as high-risk area (Coker-Vann et al., 1981).

\subsubsection{Cysticercosis in HUMANS: reports from HOSPITALS}

Clinical cases of neurocysticercosis hospitalized in Bali from 1974 alert on the presence of tapeworm larvae/cysts in the pig's muscles consider it as improper for ritual offering or consumption, thus it is like an effective meat inspection. We have observed that many Balinese people, espe- cially those in rural villages, believe that cysticerci-infected muscles of pigs or cattle is due to certain evil force that causes the measly meat to occur, rather than knowledge based on an understanding of the origin of cysticerci in pigs or cattle. Balinese people are familiar with the local word "beberasan" (literally means "resembling rice"), specifically used to refer to cysticerci-infected pig or cattle meat. Therefore, in case TAENIA infection does occur in people, it is possible that infection with taeniasis occurs most commonly from lightly infected meat, leading to the development of only a single tapeworm.

\subsection{Studies on cysticercosis in HUMANS AND pigs in BALI}

4.3.1. Cysticercosis in HUMANS: reports of cysticercosis CASES in community There are two published reports available concerning human cysticercosis in the community of Bali. Susanti (unpublished data in 1980), Department of Pathology, Udayana University reported 6 cases of subcutaneous cysticercosis, and Sutisna (1994) reported 6 cases, including 4 cases of subcutaneous cysticercosis, one case with concurrent subcutaneous cysticercosis and T. solium taeniasis, and one case with concurrent subcutaneous cysticercosis, neurocysticercosis as well as $T$. solium taeniasis. The four patients with only subcutaneous cysti- cercosis had, in each case, a single nodule, while the other two patients with subcutaneous cysticercosis and $T$. solium taeniasis both had about 40 nodules all over the body. These two patients did not realize that they harbored tapeworms in their intestines until after TAENIA eggs were recovered in their feces by microscopic examination and a single adult tapeworm expelled from each patient after anti-helminthic drug treatment, which eventually was confirmed to be $T$. solium by morphologic examination. The two cases having many subcutaneous nodules and $T$. solium taeniasis suggest that the two patients are likely to have been

until 2010 are summarized in Table 3. Wandra et al. (2016) reported a Balinese man who had to be hospitalized at Sanglah Hospital due to seizures occurring a few hours after they treated the patient with praziquantel in a rural village of Gianyar district; eventually the patient was confirmed to have both neurocysticercosis as well as $T$. SAGINATA taeniasis (by proglottid's morphology and mtDNA analysis). An ocular cysticercosis of a 9-year-old Balinese girl living in a rural village in Kubu sub-district of Karangasem was confirmed (Swastika et al., 2012). The patient was operated at Indera Hospital in Denpasar, and even- tually one intact but immature cyst could be extracted from inside the left eye.

The majority of NCC cases confirmed in Jakarta and other areas in Indonesia are Balinese (Adnjana and Djojopranato, 1961; Giri, 1978; Hadidjaja et al., 1971; Margono et al., 2002; Soebroto et al., 1960) and a female from West Kalimantan (Bonne, 1940; Hadidjaja, 1971).

\subsubsection{Cysticercosis in pigs}

Reports on cysticercosis in pigs in Indonesia is limited. Le Coultre (1928) reported a prevalence of cysticercosis of $2.0-3.0 \%$ in pigs in Bali. At that time, he pointed out that the main source of cysticercosis infection in Bali was in people's house yards where pigs were let roam free on the yards and where people also used to defecate. Simanjuntak et al. (1977) reported $2.2 \%$ of 548 persons in three villages in Bali were found to have taeniasis caused by either T. SAGINATA or T. solium AND pigs were found infected with T. solium cysticerci. Cows were not examined. Depary and Kosman (1991) made similar observations about the habits of Balinese people to defecate in the stables of domestic animals located behind their houses. A report from Indonesia Directorate Animal Health, Directorate General of Livestock Service mentioned that throughout the period of 1975-1986, out of a total of $1,047,781$ pigs slaughtered in several abattoirs in Bali, 1,208 
P. SUTISNA et AL.

$(0.08 \%)$ were infected by

T. solium cysticerci on an annual basis (Margono et al., 2005). In 1987 and 1988 no cysticercosis cases were reported from records of 297,319 pigs slaughtered (Dharmawan et al., 2012; Margono et al., 2005; Widarso et al., 2001). The numbers of pigs infected with $T$. solium, cattle and carabaos infected with T. SAGINATA in 1979 were $305 / 31,187$
ActATropica19OC

(0.98\%), 476/3,158 (15.07\%) and $12 / 801$ (1.49\%), respectively (Widarso et al., 2001).

Dharmawan et al. (1992) reported seven $(0.19 \%)$ of 5,630 pigs slaughtered in Denpasar abattoir were found to be heavily infected with cysticerci of $T$. solium. These pigs were exclusively from Karangasem. During the period of 2011-2014, Wandra et al. (2015) examined 329 serum samples from pigs in rural villages in Karangasem by ELISA and found a relatively high cysticercosis seroprevalence of $13.1 \%$ (43/329) (see Table 2). By contrast, Swastika et al. (2016) examined 60 pigs slaughtered in a government-owned abattoir located outside Amlapura, the capital city of Karangasem (urban) (Fig. 1-16), and found all were seronegative for $T$. solium cysticercosis, and on autopsy the pigs were found not to be infected with T. solium.

The seroprevalence of cysticercosis in pigs in the rural villages in Karangasem found in 2011-2014 coincides with the description of a case of ocular cysticercosis found in 2010 in one of the villages (Table 3; Swastika et al., 2012) and two cases of $T$. solium taeniasis found in the same village as well as another case of $T$. solium taeniasis in a nearby village, in a field survey undertaken in 2011 (Wandra et al., 2015). These findings, as well as other information obtained by the authors from local people during the village surveys, suggest that pigs infected with $T$. solium were distributed and slaughtered by local people within the endemic neighboring villages to make food, including "pork LAWAR". In addition, with the fact that personal and environmental sanitation is poor in the area and that pigs are let roam free at least in the day time to find food, it is assumed that transmission of $T$. solium taeniasis/cy-

sticercosis occurs among people in the focal area located on the northeastern slope of Mt. Agung where the dry season continues a half year (Wandra et al., 2015).

\subsubsection{Cysticercosis in dogs}

People living in the taeniasis/cysticercosis endemic areas in Kubu sub-district informed us that they sometimes consume dog meat (Wandra et al., 2015). Dog meat as "SATE" is also eaten elsewhere in Bali, although not commonly. Dogs have been found to be infected with viable $T$. solium cysticerci in Papua (Ito et al., 2002, 2004; Wandra et al., 2015) and hence they have the potential to act as an alternative intermediate host for $T$. solium in Bali. To date there are no reports of cysticercosis in dogs in Bali, however it is unlikely that this would have been reported other than as an incidental finding. A survey of cysti- cercosis in dogs would be valuable in providing additional information about the transmission ecology of taeniasis/cysticercosis in Bali.

\subsubsection{Cysticercosis in CATTLE CAUSED by T. saginata}

As mentioned previously, Le Coultre (1928) undertook extensive studies of bovine cysticercosis during abattoir inspections in Bali and found $20-30 \%$ of cattle to be infected. Ressang and Umboh (1962) also reported the presence of bovine cysticercosis in Bali. Widarso et al. (2001) summarized the prevalence of cysticercosis in livestock in- cluding pigs, cattle and carabaos (a type of water buffalo) from 1975 until 1988. Recent preliminary studies of local cattle screened ser- ologically at abattoirs in Denpasar revealed that serological screening was consistent with the meat inspection data and cattle harboring T. SAGINATA cysticerci were not rare but rather common as expected from many T. SAGINATA cases mentioned above (Dharmawan, personal com- munication). Two experimental infection studies in cattle have been carried out in Bali (Dharmawan et al., 2009, 2012) which resulted in the development of many cysticerci, particularly in the heart muscles.

\section{Current situation concerning transmission of Taenia species in Bali}

Recent surveys of taeniasis in Bali have identified many cases of $T$. 
P. SUTISNA et $A L$.

SAGINATA infections which are widespread. These studies have failed to identify any evidence of $T$. ASIATICA transmission in Bali.

the northeastern slope of Mt. Agung in Karangasem are endemic for $T$. solium transmission (Fig. 1) (Swastika et al., 2017). There is a half-year dry season in Bali (Wandra et al., 2015) and in all areas other than the northeastern slopes of Mt. Agung, rice is harvested three times/year. In most of the island, even during the dry season, lands are covered with green grasses. In contrast, the area of the northeastern slope of Mt. Agung has little grass nor water for everyday life during the dry season as it is in the rain shadow of the volcano (Wandra et al., 2015). This environmental situation is expected to be the same at least from the past three eruptions in 1843, 1963-1964 and 2017-2018. Therefore, T. solium transmission has at least been active in this area over one century or from 1843. Furthermore, sanitation and hygienic conditions in the endemic rural area in Kubu sub-district, Karangasem are the worst in Bali, and expected to be the worst from 1843 onwards. Poverty and the

lack of affordable animal foods in the area result in the pigs often being free roaming, especially during day time. A tour of several mountainous Banjars in Gerokgak in Buleleng in the north of the island during June 2017 found that pigs reared in these areas were kept in pens either indoor or outdoor (Fig. 1-17, -18). Villagers and local health staff in these areas remembered cysticercosis in pigs approximately 2 decades ago but have no recollection of more recent occurrences. In these areas, even during the dry season, water is running through irrigation chan- nels and the living environment appears much better than in the $T$. solium endemic area in Kubu sub-district in Karangasem. Even relatively close to the Kubu sub-district, in the Bugbug (Fig. 1-14) and Seraya Banjars (Fig. 1-15) to the south, the living environment and economy was much better. A drinking water supply system has been established and almost all pig owners keep pigs in concrete pens. Some owners keep pigs in bamboo pens (picture not shown) where pigs are often found infected with $T$. HYDATIGENA but not with $T$. solium. There was little or no evidence that pigs have access to human feces in these areas (Swastika et al., unpublished).

The situation in the Kubu sub-district in Karangasem is, however, improving. Over recent times, the government has made a substantial investment in infrastructure for providing safe drinking water supply which was under construction in the Banjars on the northeastern slope of Mt. Agung in 2016. However, disruption of normal life in the area occurred during 2017 when the Mt. Agung volcano became active. In September 2017, all villagers living around the Mt. Agung were evac- uated to safe areas. By September 2017 a total of $>80,000$ people had been evacuated, increasing to $>140,000$ by the early October. We were informed that pig owners in Kubu subdistrict killed all pigs before they were evacuated. These evacuated villagers got permission to come back their home villages from 12 July 2018, since the Mt. Agung appeared to be no more active. It is unclear what effect this disruption to the T. solium endemic area may have on the parasites' transmission in the region or the areas into which the local inhabitants and their animals were re-located.

\section{Perspectives towards prevention and control of taeniasis and cysticercosis in Bali}

Studies that so far have been carried out in Bali have shown that $T$. SAGINATA taeniasis is endemic in semi-urban and/or urban areas in Bali, while $T$. solium taeniasis is only found sporadically in focal rural or remote areas on the northeastern slope of Mt. Agung. Human cysti- cercosis cases in Bali are also found sporadically, and in the last decade their occurrence in the community tended to be even rarer compared to the situation in earlier decades. This situation is due to the improve- ment of people's personal and environment hygiene and sanitation, which is likely due to increased use of latrines in households, im- provement in the way people keep their pigs in pens, In relation to $T$. solium, we could confirm that 10 Banjars located on

health education that has been given by health workers to people, and better socio- economic status of people in general (Ito et al., 2011; Wandra et al., 2015).

While access for pigs to human feces seems to have decreased over 
the last few decades in Bali, a similar level of decline in contamination of cattle pastures does not appear to have occurred. This is evident from the continued presence of relatively large numbers of cases of T. SAGI- NATA taeniasis which does not appear to have a restricted distribution in the island.

Socio-cultural aspect of the Balinese Hindu community's cultural practices concerning foods continues to be a major factor in the trans- mission of $T$. SAGINATA and $T$. solium. Consumption of undercooked pork (pork "LAWAR") is linked to frequent religious and ritual festivals. The issue was discussed extensively in 1965 at the Symposium on "Health Problems in the Hindu Traditions and Religion in Bali" held at Udayana University. Many physicians and other health workers, experts of tra- ditions and prominent leaders of Hindu religion, University academi- cians etc. participated in the symposium. They concluded that the high prevalence of taeniasis in Bali was due to the habit of Balinese people to consume pork or beef "LAWAR" made of raw meat and they re-commended that people should consume well-cooked "LAWAR" instead of raw "LAWAR". This information is mentioned by Ngoerah (1975). It

seems, however, that there has been little change in these practices; in June 2017 we observed celebratory preparations for a young woman's impending birth of a child which included preparation of large quan- tities of pork "LAWAR" in Kubu subdistrict.

In the veterinary sector, it is crucial to ensure improvement of meat inspection in abattoirs, control of clandestine abattoirs, as well as im- provements in the way people keep their animals (cattle and pigs). In the health sector, improvement of people's personal and environment hygiene and sanitation, especially in the use of hygienic latrines in households, should be given priority in the prevention and control program, so, health education for people, especially in known endemic areas should be carried out regularly in a manner people can easily understand. In addition, rapid and sensitive laboratory methods for screening taeniasis/cysticercosis as well as sufficient provision of safe and effective anthelmintic for treating cases are

parasite, such as a porcine cysticercosis control program (Lightowlers and Donadeu, 2017).

\section{Conclusion}

Bali remains endemic for $T$. SAGINATA and $T$. solium. There is no evidence for the presence of $T$. ASIATICa on Bali. Economic advancement in Bali and the associated improvements in sanitary conditions and public education have been associated with a reduction in $T$. solium transmission. Transmission now appears to be restricted to Kubu sub- district, Karangasem district on the eastern end of the island (Fig. 1). Recent improvements in water supplies and the building of well-de- signed toilets in this district as well is likely to result in a further con- traction in the parasite's transmission. We believe that with continued investment by the government and sustained monitoring, diagnostic efforts, treatment of cases of taeniasis and scientific research in the area has a good prospect of seeing the elimination of $T$. solium and neuro- cysticercosis from Bali. Research is warranted on the effects that the

recent relocation of the population from the T. solium endemic area due to activity of the Mt. Agung volcano.

\section{Financial support}

The major work from 1996 onwards published as joint projects with Japanese was supported by Grant-in-Aid for scientific research (19942014), Asia-Africa Scientific Platform Funds (2006-2008, 2009-2011) from the Japan Society for the Promotion of Science (JSPS), and the Special Coordination Fund for Promoting Science and Technology (2003-2005, 2010-2012) to A. Ito from the Ministry of Education, Culture, Sports, Science \& Technology in Japan (MEXT). equally important. Above all, in order such prevention and control program to be suc- cessful, it is essential that the Government, both on the national and provincial levels, should be committed to support the program (Gemmell et al., 1983; Ito et al., 2011; Lightowlers and Donadeu, 2017; Sutisna, 2002; Wandra et al., 2011, 2015).

With the current limited areas where T. solium is transmitted in Bali, there are good prospects for the parasite to be eliminated from the island. Continued improvement in living conditions and sanitation, as has occurred during the recent past in all other areas in Bali, is likely to result in improved sanitation and improvements in pig rearing prac- tices. There is an excellent chance for the local Government to imple- ment a sustained education campaign, including about eating pork only after cooking well. Education of local people on the risk of neurocys- ticercosis, the link with outdoor defecation with free roaming pigs, and the need to cook pork for preparation of "pork LAWAR" might eliminate neurocysticercosis from Bali. It should be reminded that such actions for health education through local radio broadcast stressed that "LAWAR" should be well cooked in over 4 decades ago (Simanjuntak et al., 1977). Sustainable education is the essential key action for elimination of food- borne infectious diseases including taeniasis which can cause secondary cysticercosis in humans and pigs, but it has taken over 4 decades for people to change their dietary habits. Although the present situation in

Bali might be the final stage in front of the goal of elimination of $T$. solium cysticercosis through education, improvement of living environment with better economy, health education for eating cooked meat and surveillance of $T$. solium cysticercosis should be strengthened for declaration of $T$. solium free island, Bali. Through such sustainable education and introduction of meat inspection in abattoirs may de- crease taeniasis of T. SAGINATA much easier than $T$. solium. Should eco- nomic advancement, improvements in sanitation and pig rearing practices not lead to the absence of $T$. solium transmission, the limited areas of endemicity would make Bali an excellent site for im-plementation of an elimination program directed specifically to the

\section{Acknowledgements}

We dedicate this article to Prof. Ketut Suastika, the former Rector of Udayana University (August 2013 - July 2017). This article was prepared based on "the International One-day Seminar focusing on combating taeniasis/cysticercosis" held on 19 June 2017 at Faculty of Medicine, Udayana University. Prof. Ketut Suastika organized another one-day international workshop entitled "Strengthening of Prevention and Control of Taeniasis/Cysticercosis and Soil Transmitted Helminthiases in Bali, Indonesia" on 22 September 2014 (Wandra et al., 2015). The authors would like to thank Indah Budi Apsari and Wayan Winiati for providing some of the references for this paper and photos on Lawar and Komoh.

\section{References}

Abouladze, K.I., 1964. Principals of Cestodology. Vol. IV. Taeniidae - Cestodes of Animals and Man and the Diseases They Provoke. Akademii Nauk USSR, Moscow.

Adnjana, I.G.N.P., Djojopranoto, M., 1961. Cysticercosis under the skin in humans. Madjalah Kedokteran Indonesia 11, 188-189 (in Indonesian).

Anantaphruti, M.T., 2005. Human taeniasis in Thailand. In: Ito, A., Wen, H., Yamasaki, H. (Eds.), Asian Parasitology 2, Taeniasis/Cysticercosis and Echinococcosis in Asia. The Federation of Asian Parasitologists, Chiba, Japan, pp. 89-98.

Anonymous. 1974-1977. Bulletin Epidemiologi Veteriner, Direktorat Jendrai peternakan, Departement Pertanian, Jakarta [Bulletin of Veterinary Epidemiology. Directorate General of Husbandry, Department of Agriculture, Jakarta].

Arambulo, P.V., Cabrera, B.D., Tongson, M.S., 1976. Studies on the zoonotic cycle of TAENIA SAGINATA taeniasis and cysticercosis in the Philippines. Int. J. Zoonoses 3 (2), $77-104$.

Bakta, I.M., Soewarno, H., 1983. Taeniasis in Banjar Saba, Village of Penatih, Bali. Proceedings of the 3rd Congress of the Indonesian Association of Internists (in Indonesian).

Bellwood, D.R., Wainwright, P.C., Fulton, C.J., Hoey, A.S., 2006. Functional versatility supports coral reef biodiversity. Proc. R. Soc. B 273 (1582), 101-107.

Bollongino, R., Burger, J., Powell, A., Mashkour, M., Vigne, J.D., Thomas, M.G., 2012 Modern taurine cattle descended from small number of near-eastern founders. Mol. Biol. Evol. 29 (9), 2101-2104. 
Bonne, C., 1940. De lintwormen van den mensch in Indie [The Tapeworms of man in the East Indies]. Samenvattend overzicht. Geneeskundig Tijdschrift voor NederlandscheIndie. 80 (40), 2376-2384 (in Dutch).
Bowles, J., McManus, D.P., 1994. Genetic characterization of the Asian TAENIA, a newly described taeniid cestode of humans. Am. J. Trop. Med. Hyg. 50 (1), 33-44.

Bradley, D.G., Loftus, R.T., Cunningham, P., MacHugh, D.E., 1998. Genetics and domestic cattle origins. Evol. Anthropol. 6, 79-86.

Brown, P., Sutikna, T., Morwood, M.J., Soejono, R.P., Jatmiko Saptomo, E.W., Due, R.A., 2004. A new small-bodied hominin from the Late Pleistocene of Flores, Indonesia. Nature 431 (7012), 1055-1061.

Cabrera, B.D., 1965. Multiple infection with adult TAENIA solium: A case report. Acta Med. Philippina 1, 147-150.

Center for Statistical Data of Bali Province, 2015. Geographic and Demographical Data of Bali Province (unpublished). .

Chung, W.C., Bruce, C.F.K., 1976. Treatment of TAENIA SAGINATA with mixture of areca nuts and pumpkin seeds. Zhonghua Min Guo Wei Sheng Wu Xue Za Zhi 9 (1-2), 31-35.

Coker-Vann, M.R., Subianto, D.B., Brown, P., Diwan, A.R., Desowitz, R., Garruto, R.M., Gibbs, C.J.Jr., Gajdusek, D.C., 1981. ELISA antibodies to cysticerci TAENIA solium in human population in New Guinea, Oceania, and Southeast Asia. Southeast Asia J. Trop. Med. Public Health 12 (4), 499-505.

Coker-Vann, M.R., Brown, P., Gajdusek, D.C., 1984. Serodiagnosis of human cysticercosis using a chromatofocused antigenic preparation of TAENIA solium cysticerci in an enzyme-linked immunosorbent assay (ELISA). Trans. R. Soc. Trop. Med. Hyg. 78 (4), 492-496.

Cross, J.H., Clarke, M.D., Cole, W.C., Lien, J.C., Partono, F., Joesoef, A., Kosin, E., 1976 Parasitology survey in northern Sumatra, Indonesia. J. Trop. Med. Hyg. 79 (6), 123131.

de Queiroz, A., Alkire, N.L., 1998. The phylogenetic placement of TAENIA cestodes that parasitize humans. J. Parasitol. 84 (2), 379-383.

De Seze, S., Laplane, L., Fimbel, M., 1938. Cysticercose opto-chiasmatique [Cysticercosis of the optic chiasma]. Bulletin et Memoires de la Societe Medicale des Hopitaux de Paris. 1202-1206 (in French).

Depary, A.A., 2000. Beberapa karakteristik TAENIA SAGINATA ASIATICA dari Pulau Samosis [Some morphological characteristics of Asian TAENIA SAGINATA from Samosir Island] Mj. Parasitol. Indon. 13, 11-18 (in Indonesian).

Depary, A.A., 2003. Taeniasis saginata asiatica in Samosir. Ara 36, 30

Depary, A.A., Kosman, M.L., 1991. Taeniasis in Indonesia with special reference to Samosir Island, north Sumatra. Southeast Asian J. Trop. Med. Public Health 22 (Suppl), 239-241.

Desowitz, R.S., 1981. New Guinea Tapeworms and Jewish Grandmothers: Tales of Parasites and People. W.W. Norton \& Company, New York.

Desowitz, R.S., Margono, S.S., Sutjahjo, S., Simanjuntak, G., 1977. Observations on the application of counter immunoelectrophoresis for the seroepidemiology of human cysticercosis. Southeast Asian J. Trop. Med. Public Health 8 (3), 303-307.

Dharmawan, N.S., 1995. TAENIA SAGINATA in Bali: A species or a strain? A Paper Presented in the 7th Regional Scientific Meeting of Medical Parasitology, Denpasar (in Indonesian).

Dharmawan, N.S., Siregar, E.A.A., He, S., Hsibuan, K.M., 1992. Cysticercosis in pigs in Bali. Hema Zoa 75, 25-37.

DHARMAWAN, N.S., HE, S., GEERTS, S., 1993. THE POSSIBILITY OF THE EXISTENCE OF TAENIA TAIWANENSIS in Bali, Denpasar, Bali. Presented at National Seminar of Parasitology VII (in Indonesian).

Dharmawan, N.S., Damriyasa, I.M., Kapti, I.N., Sutisna, P., Okamoto, M., Ito, A., 2009 Experimental infection of TAENIA SAGINATA eggs in Bali cattle: Distribution and density of Cysticercus bovis. Jurnal Veteriner 10 (4), 178-183.

Dharmawan, N.S., Swastika, K., Putra, I.M., Wandra, T., Sutisna, P., Okamoto, M., Ito, A., 2012. Present situation and problems of cysticercosis in animals in Bali and Papua. Jurnal Veteriner 13 (2), 154-162.

Diwan, A.R., Coker-Vann, M.R., Brown, P., Subianto, D.B., Yolken, R., Desowitz, R. Escobar, C.J.Jr., Gajdusek, D.C., 1982. Enzyme-linked immunosorbent assay (ELISA) for the detection of antibody to cysticerci of TAENIA solium. Am. J. Trop. Med. Hyg. 31 (2), 364-369.

Eom, K.S., Rim, H.J., 1993. Morphologic descriptions of TAENIA ASIATICA sp. n. Korean J. Parasitol. 3 (1), 1-6.

Fan, P.C., 1988. Taiwan TAENIA and Taeniasis. Parasitol. Today 4 (3), 86-88.

Fan, P.C., Chung, W.C., Lin, C.Y., Soh, C.T., Lee, K.T., Kosman, M.L., Kosin, E., Depari, A.A., Napitupulu, T., 1988. Studies on taeniasis in Taiwan VI. Is TAENIA from Taiwan, Korea and Indonesia a new species? Chin. J. Parasitol. 1 (1), 56-70.

Fan, P.C., Lin, C.Y., Kosman, M.L., Kosin, E., 1989. Experimental infection of Indonesian TAENIA (Samosir strain) in domestic animals. Int. J. Parasitol. 19 (7), 809-812.

FAN, P.C., KOSMAN, M.L., KOSIN, E., DEPARY, A.A., NAPITUPULU, T., 1990A. INDONESIA TAENIA and taeniasis. Yonsei Rep. Trop. Med. 21, 33-37.

Fan, P.C., Chung, W.C., Lo, C.T., Lin, C.Y., 1990b. The pig as an experimental host of TAENIA SAGINATA (Ethiopia and Madagascar strains). Ann. Trop. Med. Parasitol. 84 (1), 93-95.

Fan, P.C., Chung, W.C., Lin, C.Y., Wu, C.C., 1990c. Efficacy of niclosamid against aboriginal taeniasis in Taiwan. Chin. Med. J. (Taipei) 45, 241-245.

Fan, P.C., Chung, W.C., Soh, C.T., Kosman, M.L., 1992. Eating habits of east Asian people and transmission of taeniasis. Acta Trop. 50 (4), 305-315.

FAN, P.C., CHUNG, W.C., LIN, C.Y., WU, C.C., 2006. PIG AS A FAVORABLE ANIMAL FOR TAENIA SAGINATA ASIATICA infection. Kaohsiung J. Med. Sci. 22 (1), 1-13.

Frantz, L., Meijaard, E., Gongora, J., Haile, J., Groenen, M.A., Larson, G., 2016. The evolution of Suidae. Ann. Rev. Anim. Biosci. 4, 61-85.

Fritzsche, M., Gottstein, B., Wigglesworth, M.C., Eckert, J., 1990. Serological survey of human cysticercosis in Irianese refugee camps in Papua New Guinea. Acta Trop. 47, 69-77.

Gajdusek, D.C., 1977. Urgent opportunistic observations: the study of changing, transient and disappearing phenomena of medical interest in disrupted primitive human communities. Elliott, K., Whelan, J. (Eds.), Health and Disease in Tribal Societies 
69-94.

Gajdusek, D.C., 1978. Introduction of TAENIA solium into West New Guinea with a note on an epidemic of burns from cysticercosis epilepsy in the Ekari people of the Wissel Lakes area. Papua New Guinea Med. J. 21 (4), 329-342.

Gemmell, M., Matyas, Z., Pawlowski, Z., Soulsby, E.J.L., 1983. Guidelines for Surveillance, Prevention and Control of taeniasis/cysticercosis. WHO, Geneva.

Giri, I.W., 1978. Cysticercosis in Surabaya. Southeast Asian J. Trop. Med. Public Health 9

(2), 232-236

Groves, C.P., 2006. Domesticated and Commensal Mammals of Austronesia and Their Histories. In: Bellwood, P., Fox, J.J., Tyron, D. (Eds.), The Austronesians: Historical and Comparative Perspectives. ANU Press, Canberra, pp. 161-174.

Gunawan, W., Subianto, D.B., Tumada, L.R., 1975. Taeniasis and cysticercosis in Pania Lakes area of Irian Jaya. Bull. Penelitian Kesehatan Health Studies in Indonesia 23, 103-106.

Hadidjaja, P., 1971. Some taeniasis cases in Jakarta. Methods of diagnosis and treatment. Maj. Kedok. Indon. 21, 173-178 (in Indonesian).

Hadidjaja, P., Rukmono, B., Sjamsuhidajat Himawan, S., 1971. Another case of cysticercosis in Jakarta. Maj. Kedok. Indon. 21, 461-463.

Heinsohn, T.E., 2001. Human influences on vertebrate zoography: animal translocation and biological invasions across and to the east of Wallace's Line. In: Metcalfe, I., Smith, J.M.B., Morewood, M., Davidson, I. (Eds.), Faunal and Floral Migrations and Evolution in SE Asia-Australasia. Swets \& Zeitlinger b.v., Lisse, pp. 153-170.

Hoberg, E.P., Alkire, N.L., de Queiroz, A., Jones, A., 2001. Out of Africa: origins of the TAENIA tapeworms in humans. Proc. Biol. Sci. 268 (1469), 781-787.

Ito, A., Budke, C.M., 2014. Culinary delights and travel? A review of zoonotic cestodiases and metacestodiases. Travel Med. Infect. Dis. 12 (6 Pt A), 582-591.

Ito, A., Nakao, M., Sako, Y., Nakaya, K., 2000. Neurocysticercosis and echinococcosis in Asia: Recent advances in the establishment of highly reliable differential serodiagnosis for international collaboration. Southeast Asian J. Trop. Med. Public Health 31 (Suppl 1), 16-20.

Ito, A., Putra, M.I., Subahar, R., Sato, M.O., Okamoto, M., Sako, Y., Nakao, M., Yamasaki, H., Nakaya, K., Craig, P.S., Margono, S.S., 2002. Dogs as alternative intermediate hosts of TAENIA solium in Papua (Irian Jaya), Indonesia confirmed by highly specific ELISA and immunoblot using native and recombinant antigens and mitochondrial DNA analysis. J. Helminthol. 76 (4), 311-314.

Ito, A., Nakao, M., Wandra, T., 2003. Rapid review: Human taeniasis and cysticercosis in Asia. Lancet 362 (9399), 1918-1920.

Ito, A., Wandra, T., Yamasaki, H., Nakao, M., Sako, Y., Nakaya, K., Margono, S.S., Suroso, T., Gauci, C., Lightowlers, M.W., 2004. Review article: Cysticercosis/taeniasis in Asia and the Pacific. Vector Borne Zoonotic Dis. 4 (2), 96107.

Ito, A., Wen, H., Yamasaki, H., 2005a. Taeniasis/Cysticercosis and Echinococcosis in Asia.

Asian Parasitology 2. The Federation of Asian Parasitologists, Chiba, Japan, pp. $1-334$.

Ito, A., Nakao, M., Wandra, T., Suroso, T., Okamoto, M., Yamasaki, H., Sako, Y., Nakaya, K., 2005b. Taeniasis and cysticercosis in Asia and the Pacific: Present state of knowledge and perspectives. Southeast Asian J. Trop. Med. Public Health 34 (Suppl 4), 123-130.

Ito, A., Okamoto, M., Li, T., Wandra, T., Dharmawan, N.S., Swastika, K.I., Dekumyoy, P., Kusolsuk, T., Davajav, A., Davaasuren, A., Dorjsuren, T., Mekonnen, S.M., Negashi, Z.H., Yanagida, T., Sako, Y., Nakao, M., Nakaya, K., Lavikainen, A.J., Nkouawa, A. Mohammadzadeh, T., 2011. The first workshop towards the control of cestode zoonoses in Asia and Africa. Parasit. Vectors 4, 114.

Ito, A., Li, T., Chen, X., Long, C., Yanagida, T., Nakao, M., Sako, Y., Okamoto, M., Wu, Y. Raoul, F., Giraudoux, P., Craig, P.S., 2013. Mini review on chemotherapy of taeniasis and cysticercosis due to TAENIA solium in Asia, and a case report with 20 tapeworms in China. Trop. Biomed. 30 (2), 164-173.

Ito, A., Wandra, T., Li, T., Dekumyoy, P., Nkouawa, A., Okamoto, M., Budke, C.M., 2014 The present situation of human taeniases and cysticercosis in Asia. Recent Pat. Antiinfect. Drug Discov. 9 (3), 173-185.

Koesharjono, C. Sukartinah, S., Windianingsih, C., Panjaitan, W. Suarnawa, I.M., Subandi, 1987. Praziquantel for treatment of taeniasis (tapeworm). Indon. J. Parasitol. 1 (1), 23-31 (in Indonesian).

Kosin, E., Depary, A.A., Djohansjah, 1972. Taeniasis di Pulau Samosir [Taeniasis on the Samosir Island]. Maj. Fak. Kedok. Univ. Sumatra Utara 3, 5-11 (in Indonesian).

Kosin, E., Kosman, M.L., Fan, P.C., Depari, A.A., Napitupulu, T., 1988. Penelitian taeniasis

di pulau Samosir, Sumatera Utara [Study of taeniasis on Samosir island, North Sumatra]. Simp. Parasitol. Klinik 47-53 (in Indonesian).

Kosman, M.L., Depary, A.A., Napitupulu, T., Kosin, E., Fan, P.C., 1988. Epidemiology and chemotherapy of taeniasis in Samosir Islands, North Sumatra, Indonesia. Simp. Parasitol. Klinik 1-10 (in Indonesian).

Le Coultre, A.P., 1928. Cysticerci in Beef and Pork. A Study on Hygiene after Special Investigation of These Parasites on the Island of Bali. Netherlands University of Utrecht $248 \mathrm{pp}$, Thesis.

Lee, K.T., Kim, C.H., Park, C.G.T., Lee, M.Y., 1966. Cysticercosis and taeniasis in Chollapukdo Province. Korean J. Parasitol. 4 (1), 39-45.

Lightowlers, M.W., Donadeu, M., 2017. Designing a minimal intervention strategy to control TAENIA solium. Trends Parasitol. 33 (6), 426-434.

Loftus, R.T., MacHugh, D.E., Bradley, D.G., Sharp, P.M., Cunningham, P., 1994. Evidence for two independent domestications of cattle. Proc. Natl. Acad. Sci. U S A 91 (7), $2757-2761$.

Margono, S.S., Ito, A., Suroso, T., 2001a. The problem of taeniasis and cysticercosis in Irian Jaya. Indonesia. Med. J. Indon. 10 (2), 110-114.

Margono, S.S., Subahar, R., Hamid, A., Wandra, T., Sudewi, S.S., Sutisna, P., Ito, A. 2001b. Cysticercosis in Indonesia: epidemiological aspects. Southeast Asian J. Trop. Med. Public Health 32 (Suppl 2), 79-84.

Margono, S.S., Himawan, S., Purnama, T.A., Subahar, R., Hamid, A., Ito, A., 2002. 
Multiple cysticercus nodules in skin and brain in a Balinese woman: a case report. Med. J. Indon. 11 (3), 169-173.

Margono, S.S., Ito, A., Sato, M.O., Okamoto, M., Subahar, R., Yamasaki, H., Hamid, A., WANdrA, T., Purba, W.H., NAKAYA, K., ITO, M., CRAIG, P.S., SUROSO, T., 2003. TAENIA solium taeniasis/cysticercosis in Papua, Indonesia in 2001: detection of human worm carriers. J. Helminthol. 77 (1), 39-42.

Margono, S.S., Wandra, T., Suroso, T., Ito, A., 2005. Taeniasis and cysticercosis in Inodonesia. In: Ito, A., Wen, H., Yamasaki, H. (Eds.), Asian Parasitology 2. Taeniasis/ Cysticercosis and Echinococcosis in Asia. The Federation of Asian Parasitologists, Chiba, Japan, pp. 115-134.

Margono, S.S., Wandra, T., Swarsono, M.F., Murni, S., Craig, P.S., Ito, A., 2006 Taeniasis/ cysticercosis in Papua (Irian Jaya). Indonesia. Parasitol. Int. 55 (Suppl), s143-s148.

McManus, D.P., 1995. Improved diagnosis as an aid to better surveillance of TAENIA solium cysticercosis, a potential public health threat to Papua New Guinea. P. N. G. Med. J. 38 (4), 287-294.

McManus, D.P., Bowles, J., 1994. Asian (Taiwan) TAENIA: a species or strain? Parasitol. Today 10 (7), 273-275.

Nakao, M., Okamoto, M., Sako, Y., Yamasaki, H., Nakaya, K., Ito, A., 2002. A phylogenetic hypothesis for the distribution of two genotypes of the pig tapeworm TAENIA solium worldwide. Parasitology 124 (Pt6), 657-662.

Ngoerah, I.G.N., 1975. Cysticercosis of the brain. Majalah IImiah Universitas Udayana 9, 31-38 (in Indonesian).

Okamoto, M., Nakao, M., Tachi, E., Sako, Y., Sato, M.O., Yamasaki, H., Nakaya, K., Ito, A., 2007. Asian TAENIA species: species or subspecies? Southeast Asian J. Trop. Med

Public Health 38 (Suppl 1), 125-130.

Okamoto, M., Nakao, M., Blair, D., Anataphruti, M.T., Waikagul, J., Ito, A., 2010. Evidence of hybridization between TAENIA SAGINATA and TAENIA ASIATICA. Parasitol. Int. 59 (1), 70-74.

Owen, I.L., 2006. Current status of TAENIA solium and cysticercosis in Papua New Guinea. Parasitol. Int. 55 (Suppl), S149-S153.

Pawlowski, Z., Schultz, M.G., 1972. Taeniasis and cysticercosis (TAENIA SAGINATA). Adv Parasitol. 10, 269-343.

Rasidi, R., Margono, S.S., Simanjuntak, G.M., Koesharjono, C., 1979. Intestinal parasites in villages of Bali. J. Indon. Med. Assoc. 29, 3-5.

Ressang, A.A., Umboh, T.F.H., 1962. The concept of the veterinary public health in Indonesia. Communications Veterinariae 6, 1-11.

Salim, L., Ang, A., Handali, S., Cysticercosis Working Group in Papua, Tsang, V.C., 2009. Seroepidemiologic survey of cysticercosis-taeniasis in four central highland districts of Papua, Indonesia. Am. J. Trop. Med. Hyg. 80 (3), 384-388.

Simanjuntak, G.M., Margono, S.S., Schalan, R., Harjono, C., Rasidi, R., Sutopo, B., 1977. An investigation on taeniasis and cysticercosis in Bali. Southeast Asian J. Trop. Med.

Public Health 8 (4), 494-497.

Simanjuntak, G.M., Margono, S.S., Okamoto, M., Ito, A., 1997. Taeniasis/cysticercosis in Indonesia as an emerging disease. Parasitol. Today 13 (9), 321-323.

Soebroto, F.X., Hwa, N.T., Djojopranoto, M., 1960. Cysticercosis under the skin in humans. Maj. Kedok. Indon. 10, 460-462 (in Indonesian).

Subahar, R., Hamid, A., Purba, W., Wandra, T., Karma, C., Sako, Y., Margono, S.S. Craig, P.S., Ito, A., 2001. TAENIA solium infection in Irian Jaya (West Papua), Indonesia: a pilot serological survey of human and porcine cysticercosis in Jayawijaya District. Trans. R. Soc. Trop. Med. Hyg. 95 (4), 388-390.

Subianto, D.B., Tumada, L.R., Margono, S.S., 1978. Burns and epileptic fits associated with cysticercosis in mountain people of Irian Jaya. Trop. Geogr. Med. 30 (3), 275278.

Sudewi, A.A.R., Nuartha, A.A.B.N., 1998. Neurocysticercosis at Sanglah Central Hospital, Denpasar. A Paper Presented at the Workshop of and Annual Meeting of Indonesian Neurologist Association (in Indonesian).

Sudewi, A.A., Wandra, T., Artha, A., Nkouawa, A., Ito, A., 2008. TAENIA solium cysticercosis in Bali, Indonesia: serology and mtDNA analysis. Trans. R. Soc. Trop. Med. Hyg. 102 (1), 96-98.

Suroso, T., 2000. Petunjuk pemberantasan taeniasis/sistiserkosis di Indonesia (Guidelines for control of taeniasis and cysticercosis in Indonesia). Depkes RI. Ditjen, Jakarta - PPM \& PL, pp. 1-30 (in Indonesian).

Suroso, T., Margono, S.S., Wandra, T., Ito, A., 2006. Challenges for control of taeniasis/ cysticercosis in Indonesia. Parasitol. Int. 55 (Suppl), S161-S165.

Susanti, P., 1980. Report of six cases of sub-cutaneous cysticercosis in Balinese. Department of Pahthology, Udayana University Faculty of Medicine, Denpasar unpublished.

Sutisna, P. 1989. Parasitic infections in humans in Bali: A review. Bull. Penelitian Kesehatan (Bull. Health Res.) 17 (2), 276-283.

Sutisna, P., 1990. The problem of taeniasis in Banjar Kelod, Renon, Denpasar. Medika 16 (7), 543-549 (in Indonesian).

Sutisna, P., 1994. Cysticercosis in Bali: report of six cases. Majalah IImiah Universitas Udayana 21 (41), 5-9 (in Indonesian).

Sutisna, P., 1998. Taeniasis and cysticercosis demand for our attention (Editorial). Maj. Kedok. Udayana 39, 159-160 (in Indonesian).

Sutisna, P., 2001. People's knowledge of TAENIA infection in the rural community of Bali. Maj. Kedok. Udayana 32, 260-266.

Sutisna, P., 2002. The problems of taeniasis and cysticercosis in Indonesia. Aspects of epidemiology and prevention. Scientific Speech for Professorship Inauguration. Udayana University 6 July 2002 (in Indonesian).

Sutisna, P., Fraser, A., Kapti, I.N., Rodriguez-Canul, R., Widjana, D.P., Craig, P.S. Allan, J.C., 1999. Community prevalence study of taeniasis and cysticercosis in Bali, Indonesia. Trop. Med. Internat. Health 4 (4), 288-294.

Swastika, K., Dewiyani, C.I., Yanagida, T., Sako, Y., Sudarmaja, I.M., Sutisna, P., Wandra, T., Dharmawan, N.S., Nakaya, K., Okamoto, M., Ito, A., 2012. An ocular cysticercosis in Bali, Indonesia caused by TAENIA solium Asian genotype. Parasitol. Int. $61(2)$, 
378-380.

Swastika, K., Dharmawan, N.S., Suardita, I.K., Kepeng, I.N., Wandra, T., Sako, Y., Okamoto, M., Yanagida, T., Sasaki, M., Giraudoux, P., Nakao, M., Yoshida, T. Dhiarthini, L.P.E., Sudarmaja, I.M., Purba, I.E., Budke, C.M., Ito, A., 2016. Swine cysticercosis in the Karangasem district of Bali, Indonesia: An evaluation of serological screening methods. Acta Trop. 163, 46-53.

Swastika, K., Wandra, T., Dharmawan, N.S., Sudarmaja, I.M., Saragih, J.M., Diarthini, L.P.E., Ariwati, L., Damayanti, P.A.A., Laksemi, D.A.A.S., Kapti, N., Sutisna, P., Yanagida, T., Ito, A., 2017. Taeniasis caused by TAENIA SAGINATA in Gianyar town and TAENIA solium in Karangasem villages of Bali, Indonesia, 2011-2016: How to detect tapeworm carriers, anamnesis or microscopy? Acta Trop. 174, 19-23.

Tesfa-Yohannes, T.M., 1990. Effectiveness of praziquantel against TAENIA SAGINATA infections in Ethiopia. Ann. Trop. Med. Parasitol. 84 (6), 581-585.

Theis, J.H., Goldsmith, R., Flisser, A., Koss, J., Chioino, C., Plancarte, A., Segura, A., Widjana, D.P., Sutisna, P., 1994. Detection by immunoblot assay of antibodies to TAENIA solium cysticerci in sera from residents of rural communities and from epileptic patients in Bali, Indonesia. Southeast Asian J. Trop. Med. Public Health 25 (3) 464-468.

Tumada, L.R., Margono, S.S., 1973a. Cysticercosis in the area of the Wissel Lakes, West Irian. Southeast Asian J. Trop. Med. Public Health 4 (3), 371-376.

Tumada, L.R., Margono, S.S., 1973b. Intestinal helminthic infection in the Paniai highlands, with special reference to TAENIA and Hymenolepis NANA. Maj. Keok. Indoensia 23, 103-106.

Tumada, L.R., Subianto, D.B., 1974. Combustio epidemic in the Wissel Lakes. Mimeographed Report. Department of Public health, Jayapura, West Irian 3pp Cited by Gajdusek (1977).

Wandra, T., Subahar, R., Simanjuntak, G.M., Margono, S.S., Suroso, T., Okamoto, M., Nakao, M., Sako, Y., Nakaya, K., Schantz, P.M., Ito, A., 2000. Resurgence of cases of epileptic seizures and burns associated with cysticercosis in Assologaima, Jayawijaya, Irian Jaya, Indonesia, 1991-95. Trans. R. Soc. Trop. Med. Hyg. 94 (1), 46-50.

Wandra, T., Ito, A., Yamasaki, H., Suroso, T., Margono, S.S., 2003. TAENIA solium in Irian Jaya, Indonesia. Emerg. Infect. Dis. 9 (7), 884-885.

Wandra, T. Sutisna, P., Dharmawan, N.S., Margono, S.S., Sudewi, R., Suroso, T., Craig, P.S., ITO, A., 2006A. HIGH PREVALENCE OF TAENIA SAGINATA taeniasis and status of TAENIA solium cysticercosis in Bali, Indonesia, 2002-2004. Trans. R. Soc. Trop. Med. Hyg. 100 (4), 346-353.

Wandra, T., Depary, A.A., Sutisna, P., Margono, S.S., Suroso, T., Okamoto, M., Craig P.S., Ito, A., 2006b. Taeniasis and cysticercosis in Bali and north Sumatra, Indonesia.

Parasitol. Int. 55 (Suppl), s155-s160.

Wandra, T., Margono, S.S., Suroso, T., Wibisono, H., Ito, A., 2007a. Taeniasis/cysticercosis in Indonesia. Southeast Asian J. Trop. Med. Public Health 38 (Suppl 1), 140143.

Wandra, T., Margono, S.S., Gafar, M.S., Saragih, J.M., Sutisna, P., Sudewi, A.A.R.

Depary,

A.A., Yulfi, H., Darlan, D.M., Okamoto, M., Sato, M.O., Sako, Y., Nakao, M., Nakaya,

K., Craig, P.S., Ito, A., 2007b. Current situation of taeniasis and cysticercosis in

Indonesia. Trop. Med. Health 35 (4), 323-328.
Wandra, T., Sudewi, R., Swastika, I.K., Sutisna, P., Dharmawan, N.S., Yulfi, H., Darlan, D.M., Kapti, I.N., Samaan, G., Sato, M.O., Okamoto, M., Sako, Y., Ito, A., 2011. Taeniasis/cysticercosis in Bali, Indonesia. Southeast Asian J. Trop. Med. Public Health 42 (4), 793-802.

Wandra, T., Ito, A., Swastika, K., Dharmawan, N.S., Sako, Y., Okamoto, M., 2013. Taeniasis and cysticercosis in Indonesia: past and present situations. Parasitology 140 (13), 1608-1616.

Wandra, T., Swastika, K., Dharmawan, N.S., Purba, I.E., Sudarmaja, I.M., Yoshida, T., Sako, Y., Okamoto, M., Diarthini, L.P.E., Laksemi, D.A.A.S., Yanagida, T., Nakao, M., Ito, A., 2015. The present situation and towards the prevention and control of neurocysticercosis on tropical island Bali, Indonesia. Parasit. Vectors 8, 148.

Wandra, T., Sudewi, R., Susilawati, N.M., Swastika, K., Sudarmaja, I.M., Eka Diarthini, L.P., Purba, I.E., Okamoto, M., Budke, C.M., Ito, A., 2016. Neurocysticercosis diagnosed in a patient with TAENIA SAGINATA taeniasis after administration of praziquantel: a case study and review of the literature. Prim. Health Care Open Access 2016.6.3.

Waruju, B., 1988. Problema taeniasis dan sistiserkosis di Bali [The problem of taeniasis and cysticercosis in Bali]. Maj. Parasitol. Indon. 1, 19-25.

Widarso, H.S., Purba, W.H., Wandra, T., Suroso, T., 1999. Masalah pada pemberantasan taeniasis/cysticercosis di Indonesia, khususnya di Irian Jaya [The problems of the control program of taeniasis/cysticercosis in Indonesia particularly in Irian Jaya]. Scientific Session Konas V Petri, Konas VII P4I and PKWI, Makassar (in Indonesian). .

Widarso, H.S., Margono, S.S., Purba, W.H., Subahar, R., 2001. Prevalensi dan distribusi taeniasis dan sistiserkosis [prevalence and distribution of taeniasis and cysticercosis] Makara, Kesehatan 5, 34-38 (in Indonesian).

Widjana, D.P., Kapti, I.N., 1983. Some aspects of taeniasis in the sub-district of Abiansemal (in Indonesian). Paper Presented in Congress and Scientific Meeting of Medical Microbiology and Parasitology of Indonesia.

Yamane, K., Suzuki, Y., Tachi, E., Li, T., Chen, X., Nakao, M., Nkouawa, A., Yanagida, T., SAKO, Y., ITO, A., SATO, H., OKAMOTO, M., 2012. RECENT HYBRIDIZATION BETWEEN TAENIA ASIATICA and TAENIA SAGINATA. Parasitol. Int. 61 (2), 351-355.

Yamane, K., Yanagida, T., Li, T., Chen, X., Dekumyoy, P., Waikagul, J., Nkouawa, A., Nakao, M., Sako, Y., Ito, A., Sato, H., Okamoto, M., 2013. Genetic relationships between TAENIA SAGINATA, TAENIA ASIATICA and their hybrids. Parasitology 140 (13), 1595-1601.

Yamasaki, H., Allan, J.C., Sato, M.O., Nakao, M., Sako, Y., Nakaya, K., Quu, D., Mamuti, W., Craig, P.S., Ito, A., 2004. DNA differential diagnosis of taeniasis and cysticercosis by multiplex PCR. J. Clin. Microbiol. 42 (2), 548-553.

Zarlenga, D.S., McManus, D.P., Fan, P.C., Cross, J.H., 1991. Characterization and detection of a newly described Asian taeniid using cloned ribosomal DNA fragments and sequence amplification by the polymerase chain reaction. Exp. Parasitol. 72 (2), 174183.

Zein, U., Siregar, S., Janis, I., Pane, A.H., Purba, J.M., Sardjono, T.W., Wandra, T., Swastika, K., Lim, H., Yanagida, T., Okamoto, M., Ito, A., 2019. Identification of a previously unidentified endemic region for taeniasis in North Sumatra, Indonesia. Acta Trop. 189, 114-116. 